\title{
Construction of the Kyushu Private Railway in Japan And Technology Transfer from the Germany
}

\author{
Ichiro Tsutsumi: Senior Researcher, \\ The Institute of Vocational Training, \\ Polytechnic University of Japan \\ 4-1-1, Hashimotodai, Sagamihara, Kanagawa, 2291196, Japan \\ E-mail: ictutumi@,uitec.ac.jp \\ Hiroshi Ikemori: Professor \\ Nishi-Nippon Institute of Technology \\ 1-11, Aratsu, Kanda, Fukuoka, 8000394, Japan \\ E-mail: ikemori@mec.nishitech.ac.jp
}

\begin{abstract}
In this paper, railway construction of the Kyushu Private Railway in Japan and technology transfer from the Germany will be explained. The early stage of Japanese railway construction, many foreign engineers employed, and many of them were Englishmen, for railway construction of Main Island. But, railway construction of Kyushu and Hokkaido Island were different from it. The former introduced German technology, and the latter employed American one. The nationalization of Japanese main private railways as Nippon Railway and Sanyo Railway from 1906 to 1907, these different technologies will be generalized as Japanese own railway technology after establishment of the Railway Agency of Japan (R.A.J.) in 1908.

The contents of this paper are as follows.

1) A short history of the Kyushu Private Railway.

2) A foreign railway engineer, Mr. Hellmann Rumschottel.

3) Two examples of imported German technology and industrial heritages.

4) Conclusion of this paper.
\end{abstract}

Keywords: Technology, History of technology, Kyushu Railway, Technology transfers.

\section{A short history of the Kyushu Private Railway}

The Kyushu Private Railway Co. was established on Aug. 1888. At the same time, a foreign engineer Mr. Hermann Rumschottel was engaged from Germany. After arrived at Japan, he gave an order for rolling stocks and other railway materials for construction to the Dortmund Union Co. in Germany. On Sep. 1888, the first railway construction had been started. The Nippon Doboku Co. (now, Taisei Kensetsu Co.) had a contract to construct this railway.

On Mar. 1890, from Hakata to Kurume railway construction was completed and railway transport business had been started. There were three train operation services per diem in those days. The departure and arrival times of these two stations were as follows ${ }^{1)}$.

1) Hakata to Kurume train operation services

Hakata, 7:10, 12:10 and 16:10 $\rightarrow$ Kurume, 8:33, 13:33 and 17:33

2) Kurume to Hakata train operation services 
Kurume, 9:10, 14:10 and 18:10 $\rightarrow$ Hakata, 10:33, 15:33 and 19:33

After this, the railway transport business opening process was as follows ${ }^{2}$. They are now continued as Kagoshima Line, Sasebo Line, and Nagasaki Line of the Kyushu Railway Co. (JR Kyushu Co.).

1) Nov. 1890: Hakata to Ongagawa

2) Feb. 1891: Ongagawa to Kurosaki, Apr. 1891: Kurosaki to Moji,

Jul. 1891: Kurume to Kumamoto, Aug. 1891: Tosu to Saga

3) Apr. 1895: Kokura to Yukuhashi,

4) Nov. 1896: Kumamoto to Yatsushiro

5) Jul.1897: Saga to Haiki

6) Jan. 1898: Haiki to Sasebo and Haiki to Omura, Nov.1898: Omura to Nagasaki

7) Dec. 1902: Kokura to Kurosaki. and so on.

There was a Chikuho Private railway in the north Kyushu Ireland. This railway had been started its railway transport business on Aug. 1891 from Wakamatsu to Nohgata. This railway was a coaler of the Chikuho coalfields that owned by the Mitsubishi Co. and had a junction at Orio station of the Kyushu Private Railway. On Oct. 1897, Kyushu Private Railway merged this coaler. Figure 1 shows a railway map of the Kyushu Private Railway in $1905^{3)}$.

On July 1907, the Kyushu Private Railway was purchased by Japanese Government and constructed one of the trunk lines of the Japanese National Railway (later, Railway Agency of Japan: R.A.J.).

\section{A foreign railway engineer, Mr. Hellmann Rumschottel}

A foreign railway engineer, Mr. Hellmann Rumschottel (1844-1932) was born at the Trier in Germany on Nov. 1844. He graduated at the Prussian Technical and Art Institute, and associated Railway Division of Berlin City, German Railway Construction Co., and Prussian National Railway (P.N.R.). In this P.N.R., he was a chief mechanical engineer ${ }^{4)}$.

In 1887, he was engaged to the Kyushu Private Railway of Japan. He gave an order for steam locomotives to Hohenzollern Steam Locomotive Co. and Krauss-Maffei Co.. Coaches and wagons were gave an order to the Van Der Ziepen Co. and other railway materials for construction to the Dortmund Union Co. in Germany. He made a great contribution to not only railway technology but also management of railway transport business for Kyushu Private Railway ${ }^{4)}$.

He related to construction of the Besshi Copper Mine Railway of Ehime Pref. at Shikoku Ireland. The Sumitomo Co. had this industrial railway. And he related design of the Tokyo City Overhead Railway construction. He returned to his country in 1887 and in charged of the Prussian National Railway again. He had been suffering from ill health, which terminated in his death on Sep. 1932 at Berlin.

\section{Two examples of imported German technology and industrial heritages.}

Two examples of imported German technology will be introduced here. These are called as the Industrial Heritage and we will explain to them. 


\section{1) Steam Locomotive}

The first imported steam locomotive of Kyushu Private Railway was Nos. 1 3, and made by the Hohenzollern Steam Locomotive Co. at Dusseldorf in 1889. These were all 0-4-0 tank engines. Another these steam locomotives, 14 coaches and 34 wagons were imported from Germany too.

In 1889 and 1990, 11 steam locomotives were imported. These Nos.4 14 were all 0-4-0 tank engine and made by the Krauss-Maffei Co. at Munich. In 1891, four it type 0-4-0 steam tank engines (later five same type 0-4-0 tank engines were added in 1894) made by the Krauss-Maffei Co. were imported. In many of them, Usa City of Oita Pref now preserves one steam tank engine at the Usa shrine. This is a Class 10 No.26 of the R.A.J. (former No.19 of the Kyushu Private Railway) 0-4-0 steam tank engine, and designated as the Cultural Properties of Oita Pref. on Jan.2005. Figure 2 shows this 0-4-0 tank engine.

2) Coach

There is a third class four-wheel wooden coach that is now preserved in the Kyushu Railway Museum of Kita-kyushu City. Former, this brick-made beautiful building was a head office of Kyushu Private railway Co.. The Kokura Works of Kyushu Private Railway made this coach in 1887. With elongation of the Kyushu Private Railway, many coaches and wagons needed. So, Kokura works made these rolling stocks with reference to German made four-wheel wooden coach and wagons. There were two German engineers Mr. Louis Garland as a mechanical engineer and Mr. Kahr Duissung as a driver of steam engines employed. They gave assistance to Mr. Hellmann Rumschottel and probably, Mr. Louis Garland gave a lead to Japanese technicians to build wooden coaches and wagons.

\section{Conclusion of this paper}

The author explained German railway technology transfer through two examples as before. It was a special case of Japanese railway construction. This introduction of Metric System was the early stage of introduction in Japan. Japanese government formally participated in the International Metric System Association (it organized in 1775) in 1885.

After the Kyushu Private Railway merged Chikuho Private Railway on Oct. 1897, the former introduced an American railway engineering systems. Many 4-4-0 or 2-6-0 and 2-8-0 powerful tender type steam locomotives for express train and heavy goods train uses were imported from the Baldwin Locomotive Works of U.S.A.. As a result, German made 0-4-0 or 0-6-0 steam tank engines was transposed as branch line or coalfield's goods train operation.

The nationalization of 17 main Japanese private railways, railway engineering system was unified as English type Ft.-Lbs. system. In Kyushu Ireland, the Ft.-Lbs System reconstructed many infrastructures as bridges and station structures constructed by the Metric System. But on Apr. 1930, Ministry of Railway introduced Metric Systems, and this system has been commonly used in the railway engineering fields.

In the present, the Metric System is not only Japanese railway standard but also all production standards. German engineers introduced the roots of this system from Germany. It is a very important view of the discussion of technology transfer in Japan. 


\section{References}

1) Kogi Kawakami, The New History of Japanese Railway (2), Tetsudo Tosho Kankokai, (1968), p.317.

2) Ibid 1). pp.310-311.

3) Ibid 1), p.315.

4) The Japanese Transport Association, Memoir of Railway Forerunners, (1972).

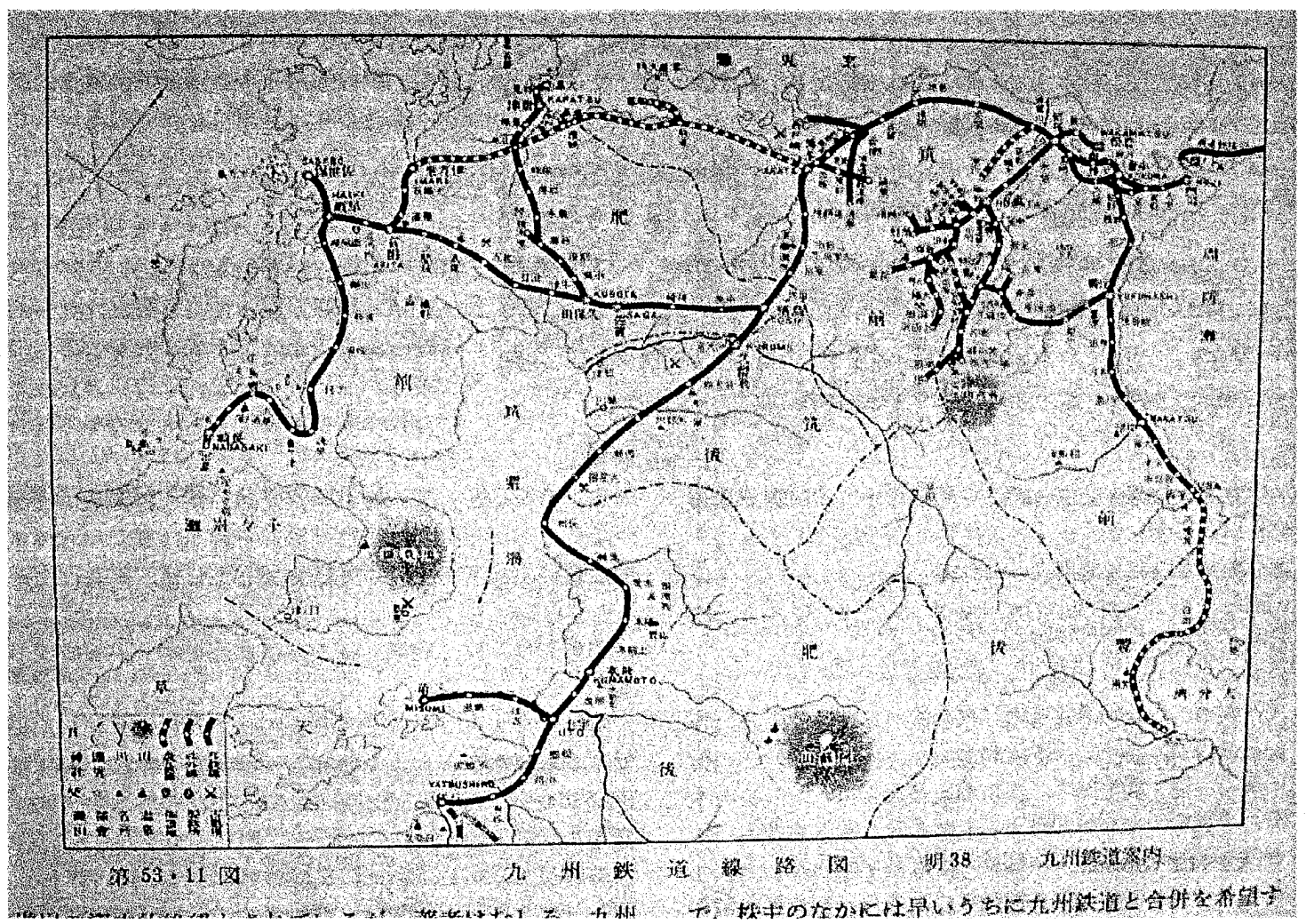

Figure 1 Railway map of the Kyushu Private Railway in 1905.

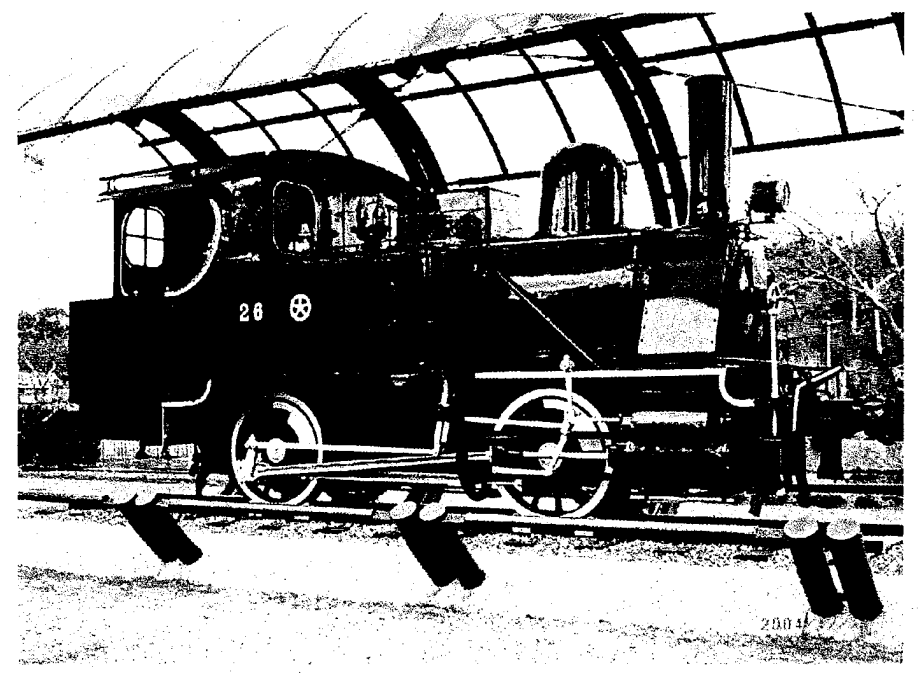

Figure 2 Class 10 No.26 0-4-0 tank engine of the R.A.J.. 